\title{
Biomedisinsk teknologi i idrett: Hvor går grensene?
}

\section{Sigmund Loland}

I denne artikkelen drøfter jeg bruk av biomedisinsk teknologi i prestasjonsfremmende hensikt i konkurranseidrett. Mer presist utforsker jeg mulighetene for å skille mellom etisk akseptabel og etisk uakseptabel bruk. Jeg kritiserer WADAs normative grunnlag for å forby visse biomedisinske midler og metoder, og argumenterer for at eventuelle forbud må bygge på tydeligere verdisyn på idrett. Jeg undersøker to idealtypiske syn og deres teknologiske implikasjoner. Det smale synet er liberalt og avviser begrensninger i bruk av biomedisinske midler og metoder blant voksne idrettsutøvere som dårlig begrunnet paternalisme. Det brede synet inneborer en mer restriktiv holdning og aksepterer en viss regulering av trening og prestasjonsutvikling også utenfor konkurransene. I en avsluttende del veier jeg det smale og det brede synet mot hverandre og reflekterer over hvilket syn som vil dominere framtidens idrett.

Nøkkelord: etikk, idrett, biomedisinsk teknologi, doping

English summary: The use of biomedical technology in sport: Are there any limits?

In the article I examine the use of biomedical technology to enhance performance in competitive sport. More specifically I examine the possibilities for distinguishing between ethically acceptable and ethically unacceptable use of such technology. I criticize the World Antidoping Agency's (WADA) normative criterion for banning certain technologies as it is vague and unclear. I argue that any ban by WADA has to build on a clear and operational normative view of sport. Two relevant ideal-typical views are examined together with their technological implications. The narrow view is liberal and rejects restrictions on the use of biomedical technology among professional athletes as unjustifiable paternalism. The wider view implies a more restrictive approach and accepts certain regulations of performance-enhancing means and met- 
hods outside of competitions. In the conclusion, I compare the narrow and the wider views and reflect upon their possible status in competitive sport in the future.

Keywords: ethics, sport, biomedical technology, doping

\section{Innledning}

Ett av de mest omdiskuterte etiske tema i idretten er bruk av biomedisinsk teknologi med prestasjonsfremmende hensikt. Noen ganger har diskusjonene en samlende effekt - for eksempel er det sterk støtte til antidopingarbeid i den norske befolkningen (Breivik, Hanstad \& Loland 2009). Andre ganger kan debattene virke splittende. Diskusjonen om såkalte høydehus har vært en kilde til uenighet blant norske utøvere og trenere i over ti år. Framtidsutfordringen portretteres på temmelig dramatisk vis. Ifølge World Anti-Doping Agency (WADA) står bruk av genteknologi i prestasjonsfremmende hensikt like for døren. ${ }^{1}$

I det følgende vil jeg drøfte etiske sider ved bruk av biomedisinsk teknologi i konkurranseidrett. Med «konkurranseidrett» mener jeg idrettsgrener med formelle konkurranseregler som er organisert i og styrt av nasjonale og internasjonale særforbund. «Biomedisinsk teknologi» viser til midler og metoder som er utviklet med basis i grunnleggende biologiske og medisinske innsikter, først og fremst for å forebygge og lege sykdom og skade. Min diskusjon vil angå bruk av slik teknologi i ikke-terapeutisk hensikt for å fremme idrettsprestasjoner. Eksempler kan være bruk av erytropoietin (EPO) for å fremme produksjon av røde blodlegemer og dermed utholdenhet, eller bruk av anabole androgene steroider (AAS) for å øke muskelstyrke og korte ned restitusjonstid etter trening.

Nasjonale og internasjonale idrettsorganisasjoner og WADA anser slike former for prestasjonsfremming for doping og som forbudte midler. ${ }^{2}$ Spørsmålet er: Hvorfor? Og hvordan kan vi trekke grenser mellom akseptabel og ikke-akseptabel bruk av biomedisinsk teknologi i idrett?

Jeg vil først diskutere tradisjonelle begrunnelser for restriksjoner på biomedisinsk teknologi, primært argumenter om fairness og helse. Jeg vil videre argumentere for at WADAs normative begrunnelse har sine mangler. $\AA ̊$ sette grenser må bygge på klarere tolkninger av idrettens normer og verdier. Jeg vil drøfte to idealtypiske idrettssyn i så måte og avslutte med å vurdere synene i forhold til utviklingstrekk i moderne idrett. 


\section{Fairness}

Et standardargument for å forby bestemte former for biomedisinsk teknologi er at slik bruk er unfair (Waddington \& Smith 2009: 35-47). Argumentet bygger på en tolkning av fairness både som en individuell forpliktelse og som en institusjonell norm.

Den individuelle forpliktelsen om fairness forstås som følger: Når vi er frivillig engasjert i en regelstyrt praksis, bør vi holde reglene (Rawls 1971: 342-350). Spill og idrett illustrerer betydningen av fairness på konkret vis. Spilleregler er det Searle (1969: 33-34) kaller konstitutive regler. Reglene skaper spillet. Forbudet mot å sparke ballen er med på å definere håndball, forbudet mot hands er et viktig kjennetegn på fotball, regler for utførelse og stil definerer turnsporten. Ønsker vi å realisere idrettskonkurranser, er vi avhengige av at andre holder reglene, og de andre er avhengige av at vi gjør det samme. Fairnessforpliktelsen bygger på forestillingen om at det er urimelig å nyte godt av andres samarbeid uten å yte vår del.

Bruk av forbudte midler og metoder, eller doping, innebærer regelbrudd for å oppnå en eksklusiv fordel. Doping er juks. For at doping skal gi fordel, er de som doper seg, avhengig av at andre holder reglene. Slik utnytter den dopede utøveren andres regelkonformitet. Dopede utøvere er gratispassasjerer som behandler andre utøvere som rene midler for egen vinnings skyld.

Men fairnessargumentet hjelper ikke som begrunnelse for dopingreglene i seg selv. Vi kan ikke begrunne en regel med å vise til at det er galt å bryte den. Mitt spørsmål handler om det normative grunnlaget for forbudet. Faktisk kan også fairnessargumentet brukes til støtte for en liberalisering av bruk av biomedisinsk teknologi (Tamburrini 2000: 50ff). Dersom et betydelig antall utøvere bryter reglene uten å bli tatt, vil regeltro utøverne få en ulempe. Moral lønner seg ikke. Situasjonen er urettferdig, og fairnessforpliktelsen er problematisk. For å gjenopprette fairness kan ett alternativ være å oppheve dopingreglene.

Antidopingforkjemperen kan så vise til institusjonell fairness og til krav om like muligheter for prestasjon (Loland 2009b). Det strukturelle målet $\mathrm{i}$ idrettskonkurranser er å måle, sammenlikne og rangere utøvernes prestasjoner etter de definisjonene som er gitt i idrettens konstitutive regler. Forutsetningen for gyldige rangeringer er pålitelige og gyldige målinger og sammenlikninger. Idrettens regler skiller ut noen ulikheter som potensielle feilkilder. For eksempel skal deltakere i de aller fleste idretter gis like ytre betingelser, utstyr skal standardiseres der dette gir mening, og utøverne skal klassifiseres etter kjønn og vekt der det framstår som rimelig. Målet er å unngå rangeringer som er betydelig påvirket av tilfeldige klimatiske variasjoner eller av forskjeller i utstyr og/eller kjønn og kroppstørrelse. Hopprenn med ustadig og sterk vind, spydkonkurranser der forskjeller i spyd avgjør utfallet, eller boksekamper mellom tungvektere og fluevektere, blir dårlige konkurranser. Konkurranseidrettens regler synes å rendyrke 
bestemte egenskaper og ferdigheter som utøvere kan påvirke selv og holdes ansvarlige for.

Her blir dopingforbudet relevant. Prestasjonsforbedring ved hjelp av biomedisinsk teknologi faller utenom ideer om en «ekte» eller en «naturlig» idrettsprestasjon. Som det het i de første dopingdefinisjonene: Doping er «kunstig» prestasjonsfremming (Tamburrini 2000: 52-54). Forbedringen bygger på eksterne ekspertsystemer, og utøvere «fortjener» ikke prestasjonsframgangen som «sin egen». Men slike argumenter er kompliserte. Hvorfor anses ulikhet i prestasjon grunnet biomedisinsk teknologi som urettferdig, mens vi aksepterer genetiske ulikheter og ulikheter i støtteapparat og økonomiske ressurser? Hvorfor er det lov med høydetrening, men ikke med EPO-bruk som gir omtrent samme fysiologiske effekt?

\section{Helse}

Det andre standardargumentet for restriksjoner på biomedisinsk teknologi er knyttet til helserisiko (Waddington \& Smith 2009: 16-34). Utstrakt bruk av prestasjonsfremmende midler og metoder kan føre til alvorlige helseskader (Hartgens \& Kuipers 2004; Tentori \& Graziani 2007). Jeg tar det som en forutsetning at det er knyttet betydelig risiko for skade og til dels død ved utstrakt bruk av for eksempel EPO og AAS.

Men ved nærmere ettersyn er også helseargumentet problematisk. Konkurranseidrett bidrar ikke alltid til helse og kan iblant være direkte skadelig. Langsiktig og hard trening innebærer å balansere kroppens anabole og katabole prosesser, og ubalanse kan resultere i overtrening. Intense trenings- og konkurransesituasjoner kan gi akutte skader som muskelstrekk og skjelettskader. I noen idretter er faktisk risiko for skade og endog død ansett som en verdifull del av aktiviteten. I fallskjermhopping og utfor på ski er det en viktig del av ferdighetskravet å kunne ta og kalkulere risiko. Et argument om å forby biomedisinske midler og metoder på grunn av helserisiko kan utvikles til et argument mot deler av toppidretten generelt.

En slik konklusjon blir likevel urimelig da den ikke skiller mellom forskjellige former for helserisiko. Ulike praksiser har ulike normer og verdier. I medisin er det overordnede målet å forebygge og lege skade og sykdom. I andre praksiser veies helse opp mot andre mål. Som angitt i det olympiske mottoet Citius, altius, fortius! (Raskere, høyere, sterkere!), er konkurranseidrett preget av et sterkt driv mot overskridelse og framgang. Helse er ikke det øverste målet, i idretter som fallskjermhopping og utfor på ski gir endog risiko verdi til aktiviteten. Helserisiko knyttet til bruk av biomedisinsk teknologi synes å være av et annet slag. Hvorfor?

Igjen dukker forestillinger om «kunstig» og «ufortjent» prestasjonsfremming opp. Helserisikoen blir ansett som «unødvendig» og irrelevant ut 
fra idrettens verdier. Den gode utøveren balanserer overtrening og skader. Eksperter i fallskjermhopping og utfor på ski kalkulerer og tar risiko uten å feile. Risikohåndtering ligger i idrettens natur. Risiko ved doping har imidlertid lite med utøverens ferdigheter å gjøre, og anses derfor som irrelevant for idrettens verdier.

\section{The Spirit of Sport}

Gjennomgang av både fairness- og helseargumentet viser at bruk av biomedisinsk teknologi utfordrer våre syn idrettens mening og verdi. Muligheter for å trekke klare grenser avhenger av en normativ teori om idrett - et tydelig, verdibasert idrettssyn.

WADA har anerkjent dette behovet. I WADAs regler heter det at biomedisinske midler og metoder skal vurderes for forbudslisten dersom de møter 2 av 3 kriterier: 1) De har dokumentert prestasjonsfremmende effekt, 2) de innebærer dokumentert helserisiko, og 3) de strider mot det WADA omtaler som «the spirit of sport». De to første kriteriene er faktabasert, det tredje kriteriet er verdibasert. WADA forklarer «the spirit of sport» som

$[\ldots]$ the celebration of the human spirit, body and mind, $[\ldots]$ characterized by the following values:

- Ethics, fair play and honesty

- Health

- Excellence in performance

- Character and education

- Fun and joy

- Teamwork

- Dedication and commitment

- Respect for rules and laws

- Respect for self and other participants

- Courage

- Community and solidarity ${ }^{3}$

Men der stopper forklaringene. En velvillig leser forstår at utstrakt bruk av en del biomedisinske midler og metoder kan stride mot disse idealene, men en kritiker kan like gjerne argumentere for at idealene støtter medisinsk kontrollert bruk av teknologi som i dag er forbudt. Mangelen på presisjon har gitt opphav til opphetede debatter. For eksempel har høydehus marginal prestasjonsfremmende effekt, men ingen kjent helserisiko. Noen er kritiske til metoden og hevder den strider mot «the spirit of sport» (Loland \& Murray 2007; Loland \& Caplan 2008). Andre hevder at høydehus kun utnytter fysiologisk adaptive responser og er ikke fysiologisk manipulerende (Levine 2007). Uenigheten angår med andre ord hva idrettsprestasjoner egentlig dreier seg om. 
En idrettsprestasjon er et komplekst produkt av et stort antall genetiske og miljømessige faktorer fra utøverens unnfangelsesøyeblikk til prestasjonsøyeblikket; det handler om alt fra det første biologiske samspillet mellom barn og mor i mors liv, omsorg og næring og generell påvirkning i oppveksten, idrettsspesifikke stimuli i form av trening og tilgang til ressurser, og til syvende og sist forhold ved selve situasjonen umiddelbart før og under prestasjonen.

Noen av disse faktorene er basert på tilfeldigheter - for eksempel er genetiske predisposisjoner og talent utfallet av «naturens lotteri». Også miljøfaktorer kan ha et tilfeldig preg. Et svømmetalent får neppe utvikling om han eller hun ikke vokser opp nært et godt svømmemiljø og med en god trener. En person med fotballtalent trenger medspillere og klubb for å bli god. Tilfeldighetene kan også spille avgjørende roller i selve konkurransesituasjonen. En plutselig vind bærer spydet en halv meter lengre. En ujevnhet $\mathrm{i}$ gressmatta gir ballen en sprett, keeper misser og ballen går inn.

Andre faktorer har et meritokratisk preg. Konkurranseidrettens samfunnsmessige budskap handler om enkeltmenneskets muligheter, og idrettsretorikken tematiserer individuell og lagmessig innsats og hardt arbeid for å nå høye mål. I moderne toppidrett er i tillegg systemstyrke avgjørende: menneskelige, økonomiske, teknologiske og vitenskapelige ressurser. Statistikken over de sterkeste nasjonale olympiske medaljesankerne ligger nær offisiell internasjonal statistikk over nasjonenes brutto nasjonalprodukt (Hanstad \& Loland 2005). Kanskje er toppidrettsresultater først og fremst et uttrykk for system-meritokrati?

Uansett, i utarbeidelsen av et verdisyn på konkurranseidrett er det kritiske spørsmålet hvilke faktorer som bør inkluderes i evaluering av prestasjoner, og hvilke faktorer som bør elimineres eller kompenseres for. Jeg skal undersøke to idealtypiske svar i så henseende og diskutere konsekvenser for teknologibruk. Jeg bruker begrepet «idealtypisk» i webersk forstand. Idealtypiske idrettssyn er ikke empirisk nøyaktige beskrivelser av bestemte syn til bestemte personer eller samfunn, men en rendyrking av noen grunnleggende element i slike syn. Ved å framstille idrettssyn på idealtypisk vis tydeliggjøres verdispenninger og etiske dilemma (Loland 2009a).

\section{Smale idrettssyn}

Fellestrekket for smale idrettssyn er at de avgrenser idrettens regelområde til konkurransene i seg selv. Idretten defineres av sine konstitutive regler, av spillereglene. Regler med restriksjoner for prestasjonsutvikling utenfor konkurransesituasjonen kan vanskelig begrunnes. Der gjelder allmenne lover og regler i det samfunnet idretten er en del av. 
Smale idrettssyn har flere typer begrunnelser. Vi finner en type i pragmatiske resonnement. Pragmatikeren kan være enig i at bruk av helsefarlige medikamenter i prestasjonsfremmende hensikt er problematisk, men sier samtidig at ulempen med restriksjoner som dopingbestemmelsene er at de koster mer enn de smaker. Ifølge Kayser og Smith (2008) er antidoping lite effektivt og har utilsiktede konsekvenser. Forbudet gjør at doping blir en undergrunnsvirksomhet med betydelig helserisiko. Argumentet er at en liberalisering vil gjøre dopingbruk mer ansvarlig og underlagt åpne, medisinske kvalitetsregimer.

En annen type begrunnelse ser i større grad biomedisinsk prestasjonsfremming som en konsekvens og forsterkning av konkurranseidrettens egen logikk. Begrunnelsen har røtter i blant annet olympisk filosofi og det olympiske mottoet Citius, altius, fortius!. Konkurranseidrett dreier seg om framskritt og grensesprenging. Pierre de Coubertin, grunnleggeren av den moderne olympiske bevegelsen, refererte til rekorden som å ha samme funksjon i den olympiske ideologi som tyngdeloven i Newtons mekanikk: Rekorden er idrettens «evige aksiom» (Loland 1995).

Det olympiske synet er utviklet som forsøk på å overskride finmaskede moralske og sosiokulturelle kontekster. Coubertins ambisjon var å skape en universell og humanistisk ideologi som sto i motsetning til det han så som forstokkede idealer i sent 1800-talls Frankrike. Nedarvede privilegier og rikdom skulle ikke lenger bestemme karriere og livsløp, det skulle den enkeltes talent og egen innsats. Den olympiske idretten skulle framstå som en ren meritokratisk sfære og danne et ideal for framtidssamfunnet.

I moderne versjoner av smale idrettssyn anses idretten å være en frontsone for det nye og bioteknologisk forbedrede mennesket (Miah 2004). Forbindelser til idéstrømninger som vitalisme, futurisme og teknologisk optimisme er tydelige. Teknologien kan gi radikal frigjøring (Cooper 1995: 810). Filosofer som Savulescu (2007) og Harris (2007) leser menneskeheten inn i en ny tidsalder med overskridelse av tradisjonelle skiller mellom det biologiske og det teknologiske og mellom det organiske og det mekaniske. Begge ser mulighetene i et klart humanistisk perspektiv: Teknologien kan styrke enkeltmenneskets autonomi og menneskelig velferd.

Smale idrettssyn har med andre ord radikale, teknologiske implikasjoner. I selve konkurransen opprettholdes strenge krav til fairness. Regler skaper idrett, og prestasjonsorienteringen krever nøyaktighet. Der forskjeller i utstyr har markant og systematisk innvirkning på prestasjon, er det nødvendig enten med standardisering eller fri tilgang til teknologi for alle. Utenfor konkurransen åpner smale idrettssyn for liberalisering. Ideer om «det naturlige» og om biologiske grenser er uttrykk for fordommer og irrasjonell tradisjonalisme. Savulescu mfl. (2004: 667) skriver følgende om den olympiske topputøveren: 
Their ideal is superhuman performance at any cost [...]. Far from being against the spirit of sport, biological manipulation embodies the human spirit - the capacity to improve ourselves on the basis of reason and judgment.

Voksne toppidrettsutøvere bør ha frihet til informerte valg og til å utvikle prestasjoner med de midlene de finner hensiktsmessige. Dopingforbudet framstår i så henseende som uberettiget paternalisme (Tamburrini 2000: 34ff; Savulescu mfl. 2004).

Tamburrini og Tännsjö (2005) diskuterer en spesiell mulighet for den framvoksende genteknologien. Gjennom genetisk modifikasjon kan kvinner kompensere for menns genetisk betingede forsprang i en del idretter. Genteknologien kan være et middel til å rendyrke menneskelige moralske kvaliteter. Har vi samme genetiske predisposisjoner når det gjelder fysiske prestasjoner, kan vi teste rene moralske kvaliteter: viljestyrke, innsats, evne og vilje til langsiktig satsing. Slik kan vi i større grad nå en ren meritokratisk idrett, der tilfeldigheter i naturens lotteri blir luket ut til fordel for ervervede og derfor mer beundringsverdige kvaliteter.

Liberale synspunkt på bruk av biomedisinsk teknologi er politisk ukorrekte og uttrykkes sjelden offentlig av idrettens egne. Erfaringer fra subkulturer innen for eksempel profesjonell sykling viser imidlertid at de har en viss utbredelse (Waddington \& Smith 2009: 129-154). Synspunktene synes også å ligge nær toppidrettens sosiale logikk. Kompromissløs jakt etter forbedringer sammenfaller med en historisk utvikling der reguleringer utenfor konkurransen har minsket. Et ofte brukt eksempel er avviklingen av amatørreglene, noe som åpnet for global deltakelse uavhengig av sosioøkonomisk status, kjønn, rase og etnisk bakgrunn (Allison 2000). For tilhengere av smale idrettssyn er antidopingreglene en anakronisme som vil forsvinne i løpet av få år. WADA er i deres øyne en siste krampetrekning.

Men smale idrettssyn kan også kritiseres. En første innvending går mot det pragmatiske argumentet om at dopingforbudet forårsaker mer skade enn nytte. Premisset for legalisering bygger på at idrettsutøvere er myndige personer som kan gjøre frie og informerte valg. Imidlertid tar ikke dette premisset høyde for det som kalles totaliseringsprosessene i moderne konkurranseidrett (Heinilä 1982). Med TV-idrett som ett av verdens mest populære underholdningsprodukter har gevinstene av idrettslig suksess økt på eksponentielt vis. Stadig flere utøvere kjemper om seieren og med stadig mer effektive midler. Pengestrømmer fra TV-avtaler og reklame har gitt mulighet for å bygge opp store idrettssystemer: utøvere, trenere, medisinsk støtteapparat, teknologier, ledere. Eliteutøvere er vevd inn i komplekse nettverk av maktforhold, der utøverens suksess er nøkkelen til systemets overlevelse. Er bruk av biomedisinsk teknologi effektivt, blir det et nødvendig middel for suksess, enten utøvere ønsker det eller ikke (Murray 1983; Green 2009). Legalisering vil antakelig medføre at kontroll over og ansvar for pre- 
stasjon forskyves ytterligere fra utøvere og over mot eksterne ekspertsystemer. Det gir derfor mening å si at dopingbestemmelsene beskytter enkeltutøveren.

En annen innvending er knyttet til den olympiske tanken om verdien av å sprenge grenser. Hvorfor er overskridelse og objektiv prestasjonsframgang mål i seg selv? Hvorfor er det verdifullt å oppheve tradisjonelle biologiske grenser med teknologi? Savulescu (2007) og Harris (2007) gir gode begrunnelser knyttet til autonomi og menneskelig velferd i en rekke sammenhenger. Men slike begrunnelser er ikke nødvendigvis gyldige for alle felt. Ulike sosiale praksiser har ulik egenart. Konkurranseidretten er bygd på spillets logikk og på å begrense de mest effektive midler, eller legge inn «unødvendige hindringer», for å nå bestemte mål (Suits 1978). Fotballens konstitutive regler forbyr berøring av ballen med hendene, selv om dette kan være effektivt for å skåre mål. Alpinisten må rundt portene før hun krysser mållinja i bunn av bakken. I gode spill balanserer reglene utfordring og ferdighetskrav på en intrikat måte og legger grunnlag for opplevelseskvalitet: dypt engasjement og spenning. Fra et slikt perspektiv har konkurransene primært egenverdi. Her ser vi slektskapet mellom idrettskonkurranser, spill og lek (Meier 1988).

Begrensninger i bruk av biomedisinsk teknologi kan begrunnes med referanse til spillets logikk. Argumentet er at idretten blir mer meningsfull når ansvaret for prestasjon først og fremst ligger hos utøveren selv og ikke hos det biomedisinske støtteapparatet. Slik styrkes idretten som en arena for engasjement og spenning og for utvikling av enkeltutøvere og lag på egne premisser.

Finnes det andre verdisyn som i større grad tar opp i seg slike tanker?

\section{Brede idrettssyn}

Et alternativ til det smale synet er et bredt idrettssyn. Her er ideen at idretten er tett forbundet med sosiokulturelle og moralske verdier i det samfunnet og den kulturen den er en del av. Idrettens regelverk har ikke bare gyldighet i konkurransene, men kan også gripe inn i trening og forberedelse til konkurranser for å styrke de verdiene som anses som viktigst.

Den brede teorien har mange røtter: klassiske antikke tanker om idrettens betydning, engelsk amatørideologi og olympisk ideologi i sin fulle form. Videre er brede teorier uttrykt hos forskere som Simon (1992), Morgan (1994), Loland (2002) og Murray (2009).

I Lolands og Murrays versjoner blir konkurranseidretten en potensielt kraftfull arena for etisk perfeksjonisme. Idretten tilbyr utøvere mening og glede i å realisere sine evner og ferdigheter til økende grad av kompleksitet. Realisering av idrettstalent er imidlertid ikke nok i seg selv. Den etiske perfeksjonismen har et dypere mål: Mennesket har en moralsk forpliktelse til å 
utvikle sine egne (og legge til rette for utvikling av andres) iboende evner og egenskaper for slik å kunne utvikle seg (og andre) som frie og ansvarlige moralske aktører. Prestasjonsutvikling kan ikke foregå med de til enhver tid mest effektive midler, men må skje på basis av utøverens naturlige forutsetninger og muligheter. Murray (2007: 514) formulerer idrettens normative egenart som følger: «Excellence in sport is meant to be the product of natural talents and their perfection by hard work and other virtuous activities.»

Hva mer spesifikt innebærer dette kravet? Og hvilke implikasjoner har det for syn på biomedisinsk teknologi? I selve konkurransesituasjonen er det sammenfall mellom det smale og det brede idrettssynet. Idrettsprestasjoner må bygge på individuell og institusjonell fairness. Alle utøvere må overholde den allment aksepterte tolkningen av reglene, og alle utøvere må gis like muligheter til prestasjon. Det er tydelige krav til utstyrsstandardisering og lik tilgang på teknologi.

I synet på bruk av biomedisinsk teknologi utenfor konkurransene skiller imidlertid det smale og det brede synet lag. Tilhengere av et bredt syn retter oppmerksomheten mot selve prestasjonsutviklingen, ikke mot prestasjonen i seg selv. For å realisere sitt potensial som moralske aktører må utøvere kunne identifiseres med og tillegges ansvar for egen prestasjon. Idrett handler om enkelutøveres beundringsverdige utvikling av eget talent.

Følgelig er tilhengere av det brede synet kritiske til ekspertadministrert teknologi. Teknologien krever minimal egeninnsats og flytter ansvar for prestasjon fra utøvere og mot eksterne ekspertsystemer. Det brede synet innebærer skepsis til antatt ufarlige varianter som høydehus og støtte til forbud mot helsefarlige teknologier som EPO og AAS. Utstrakt bruk av slik teknologi fører også til at utøvere lett ender opp i en svært sårbar situasjon. Skrekkscenariet er en idrett der utøverne blir forsøkskaniner i et gigantisk eksperiment om maksimering av den menneskelige yteevnen (Hoberman 1992).

Men også det brede synet utsettes for kritikk. Et motargument er at synet er idealistisk og uten kontakt med de harde realitetene i dagens toppidrett. Eliteidretten gir mange eksempler på at utøvere er villige til å forsøke hva som helst for å prestere bedre. Kampen mot doping kan aldri vinnes. På den annen side: Kvalitative studier av godt fungerende toppidrettsgrupper viser både ydmykhet, seriøsitet og dyptfølt perfeksjonisme (Ronglan 2007; Andersen 2009). Idrettsutøvere uttrykker mer restriktive holdninger til prestasjonsfremmende teknologi enn befolkningen generelt (Breivik mfl. 2009). Utøvere stiller strenge krav til seg selv og omgivelsene. De uttrykker ønske om frihet til å velge og ansvar for egen prestasjon. Majoriteten av utøvergruppen støtter antidoping.

En annen kritikk er at det brede synet er for vagt og utflytende. Det er ikke vanskelig å være enig i formuleringen om at prestasjonsutviklingen skal foregå på moralsk beundringsverdig vis, men hvor skal vi trekke grensene? I motsetning til det smale synet der vi kun forholder oss til fairness i 
konkurransen, problematiserer det brede synet teknologier som høydehus, og det anser bruk av midler og metoder på WADAs forbudsliste som etisk uakseptabelt. Grensedragningen virker vilkårlig og åpner for gråsoner og usikkerhet.

Murray (2009) argumenterer imidlertid for at gråsoner er et kjennetegn på ekte etiske terreng. Etiske system med krystallklare grenser bør vekke vår mistanke og representerer gjerne en type etisk reduksjonisme. Å anerkjenne eksistensen av etiske dilemma innebærer å anerkjenne betydningen av kontinuerlig, etisk drøfting og refleksjon i en forandrende omverden.

\section{Konklusjon}

Jeg har undersøkt etiske begrunnelser for restriksjoner på bruk av biomedisinsk prestasjonsteknologi. Jeg har vist at WADAs normative kriterium for grensedragning, «the spirit of sport», er upresist og vanskelig å bruke i konkrete situasjoner. Her er det behov for klart uttrykte verdisyn på idrett. Jeg skisserte to syn på idealtypisk vis, det smale synet og det brede synet, og jeg undersøkte implikasjoner for bruk av prestasjonsfremmende teknologi.

Det smale idrettssynet åpner for en liberal praksis der det kun er idrettens konstitutive regler, eller konkurransereglene, som gjelder. Utenfor konkurransene er alle prestasjonsfremmende midler og metoder tilgjengelige innenfor de regler og retningslinjer som gjelder i det samfunnet idretten er en del av. Synet har til dels bakgrunn i kost-nytte-vurderinger, til dels i begrunnelser som bygger på teknologioptimisme og på forestillinger om at en liberal tilnærming til biomedisinsk teknologi kan styrke enkeltmenneskets autonomi og menneskelig velferd.

Det brede synet, derimot, ser utstrakt bruk av biomedisinsk teknologi som en trussel mot idrettens verdier, og spesielt mot idretten som en arena for en form for etisk perfeksjonisme der frie og ansvarlige utøvere utvikler sitt naturgitte talent. Synet sammenfaller med WADAs posisjon og med offisielle syn i idrett og samfunn, og innebærer klar støtte til antidoping.

Likevel skal vi ikke avskrive det smale synet. I en verden der holdninger til og bruk av prestasjonsfremmende biomedisinsk teknologi endrer seg i liberal lei: Hvorfor skal vi være skeptiske til slik teknologi i idrett? Og dersom idrettsutøvere er modne og godt informerte aktører som selv velger hvilke prestasjonsfremmende midler og metoder de ønsker å benytte: Hva er problemet? Smale idrettssyn utfordrer våre holdninger på direkte og relevant vis. Utfordringen for tilhengere av det smale synet er å finne gode svar på spørsmålet om hvorfor prestasjonsfremmende biomedisinsk teknologi vil styrke nettopp idretten og idrettens verdier. Her mener jeg at brede idrettssyn fortsatt tilbyr de beste svarene. 


\section{Noter}

1 For WADAs syn på gendoping, se www.wada-ama.org/en/Science-Medicine/Science-topics/Gene-Doping/ [Lastet ned 15. januar 2010].

2 For internasjonalt gjeldende regler og retningslinjer for antidoping, se www.wadaama.org/en/World-Anti-Doping-Program/Sports-and-Anti-Doping-Organizations/The-Code [lastet ned 15. januar 2010].

3 Se www.wada-ama.org/rtecontent/document/code_v3.pdf, p. 3 [lastet ned 15. januar 2010].

\section{Litteratur}

Allison, L. (2000) Amateurism in sport - an analysis and a defence. London: Frank Cass.

Andersen, S. (2009) Stor suksess gjennom små, intelligente feil. Erfaringsbasert kunnskapsutvikling i toppidretten. Tidsskrift for samfunnsforskning, 4, s. 427461.

Breivik, G., Hanstad, D.V. \& Loland, S. (2009) Attitudes towards performanceenhancing substances and body modification techniques: A comparison between elite athletes and the general population. Sport in Society, 12 (6), s. 737-754.

Cooper, D.E. (1995) Technology: Liberation or enslavement? I Philosophy and Technology, red. R. Fellows, s. 7-18. Cambridge: Cambridge University Press.

Fraleigh, W. (1984) Right actions in sport. Ethics for contestants. Champaign: Human Kinetics.

Green, G.A. (2009) The role of physicians, scientists, trainers, coaches, and other nonathletes in athletes' drug use. I Performance-enhancing Technologies in Sport. Ethical, Conceptual and Scientific issues, red. T.H. Murray, K.J. Maschke \& A.A. Wasunna, s. 81-95. Baltimore: The Johns Hopkins University Press.

Hanstad, D.V. \& Loland, S. (2005) What is efficient doping control? Oslo: Norges idrettshøgskole \& World Antidoping Agency.

Harris, J. (2004) Enhancing evolution. The ethical case for making better people. Princeton, NJ: Princeton University Press.

Hartgens, F. \& Kuipers, H. (2004) Effects of androgenic-anabolic steroids in athletes. Sports Medicine, 34 (8), s. 513-554.

Heinlä, K. (1982) The totalization process in international sport. Sportwissenschaft, 12 , s. $235-254$.

Hoberman, J. (1992) Mortal engines - the science of performance and the dehumanization of sports. New York: The Free Press.

Kayser, B. \& Smith, A.C.T. (2008) Globalisation of anti-doping: The reverse side of the medal. British Medical Journal, 337, s. a584.

Levine, B. (2006) Should «artificial» high altitude environments be considered doping? Scandinavian Journal of Medicine and Science in Sports, 16, s. 297-301.

Loland, S. (1995) Pierre de Coubertin's olympism from the perspective of the history of ideas. Olympika, 1/1995, s. 55-77.

Loland, S. (2002) Fair play. A moral norm system. London: Routledge. 
Loland, S. (2009a) The ethics of performance-enhancing technology in sport. Journal of the Philosophy of Sport, XXXVI (2), s. 152-161.

Loland, S. (2009b) Fairness in sport: An ideal and its consequences. I Performanceenhancing technologies in sports. Ethical, conceptual, and scientific issues, red. T.H. Murray, K.J. Maschke \& A.A. Wasunna, s. 160-174. Baltimore: The Johns Hopkins University Press.

Loland, S. \& Caplan, A. (2008) Ethics of technological constructed hypoxic environments in sport. Scandinavian Journal of Medicine and Science in Sport, 18 (supplement), s. 70-75.

Loland, S. \& Murray, T.H. (2007) The ethics of the use of technologically constructed high-altitude environments to enhance performance in sport. Scandinavian Journal of Medicine and Science in Sport, 17 (3), s. 193-195.

Meier, K.V. (1988) Tricky triad: Playing with sport and games. Journal of the Philosophy of Sport, XV, s. 11-30.

Miah, A. (2004) Genetically modified athletes. Biomedical ethics, gene doping and sport. London: Routledge.

Morgan, W.J. (1994) Leftist theories of sport: A critique and reconstruction. Urbana: Illinois University Press.

Murray, T.H. (1983) The coercive power of drugs in sport. The Hastings Center Report, XIII, s. 24-30.

Murray, T.H. (2007) Enhancement. I The Oxford Handbook of Bioetics, red. B. Steinbock, s. 491-515. Oxford: Oxford University Press.

Murray, T.H. (2009) In Search of an Ethics for Sport: Genetic Hierarchies, Handicappers General, and Embodied Exellence. I Performance-enhancing technologies in sports. Ethical, conceptual, and scientific issues, red. T.H. Murray, K.J. Maschke \& A.A. Wasunna, s. 225-238. Baltimore: The Johns Hopkins University Press.

Rawls, J. (1971) A theory of justice. Cambridge, MA: Harvard University Press.

Ronglan, L.T. (2007) Building and communicating collective efficacy: A season-long in-depth study of an elite sport team. The Sport Psychologist, 21 (1), s. 78-93.

Savulescu, J. (2007) Genetic interventions and the ethics of enhancement of human beings. I The Oxford handbook of bioethics, red. B. Steinbock, s. 516-535. Oxford: Oxford University Press.

Savulescu, J., Foddy, B. \& Clayton, M. (2004) Why we should allow performanceenhancing drugs in sport. British Journal of Sport Medicine, 38, 666-670.

Searle, J. (1969) Speech acts. An essay in the philosophy of language. Cambridge, MA: Cambridge University Press

Simon, R.L. (2004) Fair play. The ethics of sport (2. utg.). Boulder: Westview Press.

Suits, B. (1978) The grasshopper. Games, life and utopia. Toronto: University of Toronto Press.

Tamburrini, C. (2000) «The Hand of God». Essays in the philosophy of sport. Göteborg: Acta Universitatis Gothoburgensis.

Tamburrini, C. \& Tännsjö, T. (2005) The genetic design of a new amazone. I Genetic technology and sport: Ethical questions, s. 181-197. London: Routledge.

Tentori, L. \& Graziani, G. (2007) Doping with growth hormone/IGF-1, anabolic steroids or erythropoietin: Is there a cancer risk? Pharmacological Research, 55 (5), s. 359-369.

Waddington, I. \& Smith, A. (2009) An introduction to drugs in sport: Addicted to winning? London: Routledge. 
